Article

\title{
Mechanism of Ionic Impedance Growth for Palladium-Containing CNT Electrodes in Lithium-Oxygen Battery Electrodes and Its Contribution to Battery Failure
}

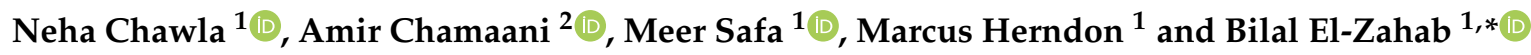 \\ 1 Department of Mechanical and Materials Engineering, Florida International University, \\ Miami, FL 33174, USA; nchaw002@fiu.edu (N.C.); msafa@fiu.edu (M.S.); mhern544@fiu.edu (M.H.) \\ 2 Department of Mechanical and Industrial Engineering, The University of Illinois at Chicago, \\ Chicago, IL 60607, USA; acham027@fiu.edu \\ * Correspondence: belzahab@fiu.edu; Tel.: +1-305-348-3558
}

Received: 30 November 2018; Accepted: 22 January 2019; Published: 23 January 2019

\begin{abstract}
The electrochemical oxygen evolution reaction (OER) and oxygen reduction reaction (ORR) and on CNT (carbon nanotube) cathode with a palladium catalyst, palladium-coated CNT (PC-CNT), and palladium-filled CNT (PF-CNT) are assessed in an ether-based electrolyte solution in order to fabricate a lithium-oxygen battery with high specific energy. The electrochemical properties of the CNT cathodes were studied using electrochemical impedance spectroscopy (EIS). Palladium-filled cathodes displayed better performance as compared to the palladium-coated ones due to the shielding of the catalysts. The mechanism of the improvement was associated to the reduction of the rate of resistances growth in the batteries, especially the ionic resistances in the electrolyte and electrodes. The scanning electron microscopy (SEM) and spectroscopy were used to analyze the products of the reaction that were adsorbed on the electrode surface of the battery, which was fabricated using palladium-coated and palladium-filled CNTs as cathodes and an ether-based electrolyte.
\end{abstract}

Keywords: EIS; Fourier-Transform Infrared Spectroscopy; cycling; catalyst; carbon nanotubes; Li- $\mathrm{O}_{2}$ battery

\section{Introduction}

Rechargeable batteries convert chemical energy to electrical energy by the reversible electrochemical reactions of reduction and oxidation. Various types of secondary battery systems that have been studied, developed, and used in the past, include nickel-metal hydride, lead-acid, lithium-ion batteries, and redox-flow batteries [1-4]. Owning to their high specific energy, lithium-ion batteries have found applications in various fields. Due to the growing demand for advanced energy storage solutions for the smart grids, automotive industries, and other consumer applications, the research for ultra-high theoretical specific energy has led to studies beyond lithium-ion batteries, where metal-air batteries have been at the forefront of this research [5-7]. Metal-air batteries are unique because the cathode material, i.e., oxygen gas, can be obtained from the atmosphere, instead of storing it in the battery. Lithium-air batteries have a high theoretical specific energy density of $3500 \mathrm{Wh} \cdot \mathrm{kg}^{-1}$ (considering the cathode), which is many folds higher than current lithium-ion batteries [8,9].

Abraham et al. first reported on a non-aqueous lithium-oxygen battery in 1996, which consisted of a lithium anode, a polymer electrolyte, and a porous carbon-air cathode [9]. Since then, several studies have been conducted to study the rechargeability of $\mathrm{Li}_{-} \mathrm{O}_{2}$ batteries. During the discharging of a $\mathrm{Li}_{-} \mathrm{O}_{2}$ battery, $\mathrm{Li}^{+}$migrates through the electrolyte to the cathode, where the incoming electrons from 
the external circuit combine with oxygen from the atmosphere to form peroxide ions, $\mathrm{O}_{2}{ }^{2-}$, which, in turn, reacts with the $\mathrm{Li}^{+}$in an oxygen reduction reaction (ORR) to form the discharge product, $\mathrm{Li}_{2} \mathrm{O}_{2}$. During charging, a reverse reaction, as well as an oxygen evolution reaction (OER) occurs, regenerating the $\mathrm{Li}^{+}$and $\mathrm{O}_{2}$. The reaction is represented as follows:

$$
2 \mathrm{Li}^{+}+\mathrm{i} \mathrm{O}_{2}+2 \mathrm{e}^{-} \leftrightarrow \mathrm{Li}_{2} \mathrm{O}_{2}
$$

Many carbonaceous materials have been used as cathodes for $\mathrm{Li}^{-\mathrm{O}_{2}}$ batteries [10]. Some of the cathode materials used have been carbon nanoparticles [11,12], carbon nanofibers [13,14], carbon nanotubes [10,12,13,15-17], graphene platelets [18,19], and other forms of carbons [20,21]. Carbon nanotubes (CNTs) are known to have high electrical conductivity, a high specific area, more numbers of accessible active sites for reactions, and better chemical stability. All these properties make them a suitable choice for use as $\mathrm{Li}_{2} \mathrm{O}_{2}$ battery cathodes [10,17,22-24].

Several metal and metal-oxide catalysts have been used in and as cathodes of $\mathrm{Li}^{-} \mathrm{O}_{2}$ batteries in order to improve the catalytic properties of the OER and ORR [25-29]. Some of the elements used have been platinum [30], palladium [31], ruthenium [26,27,32-35], gold [30,36], and various metal oxides [37-39]. The presence of a catalyst destabilizes the oxidizing species, which results in decreased charging overpotential in $\mathrm{Li}_{-} \mathrm{O}_{2}$ batteries [40-42]. It also improves the cyclability [24-27,40], and thus the overall battery performance. Gittleson et al. $[43,44]$ have shown that palladium and platinum catalysts promote $\mathrm{Li}_{2} \mathrm{O}_{2}$ oxidation at lower potentials. However, they also reported the occurrence of electrolyte decomposition that resulted in the formation of lithium carbonates, which deactivated the catalysts. The porous carbon cathode was passivated by a protective $\mathrm{Al}_{2} \mathrm{O}_{3}$ layer, applied using atomic layer deposition by Khalil et al. [21] prior to coating Pd catalysts. Their approach led to the formation of a nanocrystalline $\mathrm{Li}_{2} \mathrm{O}_{2}$ during discharge that helped improve the electronic transport properties, thus reducing the charge over-potential to about $0.2 \mathrm{~V}$ [21]. According to $\mathrm{Li}$ et al., Ru nanocrystals, when used as catalysts, decomposed $\mathrm{Li}_{2} \mathrm{CO}_{3}$ at $3.5 \mathrm{~V}$, thus reducing the accumulation of $\mathrm{Li}_{2} \mathrm{CO}_{3}$ in in the cathode during cycling.

In order to overcome the agglomeration of catalysts and deactivation of $\mathrm{Li}^{-} \mathrm{O}_{2}$ batteries, dispersing catalysts were dispersed in polymeric membranes over the oxygen electrode, and an atomic layer deposition was used to chemically bind the catalysts to the surface of carbon nanotubes, where the CNTs were then filled with catalysts [10,35,45-48]. In our previous work, we filled the CNT annulus with palladium nanocatalysts and reported increased stability of the electrolyte during the charge and discharge process [10]. In addition, the full discharge of the battery to $2 \mathrm{~V}$ resulted in a six-fold increase in the first discharge capacity compared to the pristine CNT cathodes, and over $35 \%$ for their PC-cathodes.

In this paper, we investigate and report the electrochemical impedance performance of PC-and PF-CNT cathodes during charge/discharge cycling to unveil the failure mechanism of the batteries. We also investigate the chemical nature and morphology of deposits on the electrodes using FTIR (Fourier Transform Infrared Spectroscopy) and scanning electron microscopy (SEM) to corroborate the results from the electrochemical impedance spectroscopy (EIS) study.

\section{Experimental}

Materials: Bis (trifluoromethane) sulfonamide with a purity of $>99.8 \%$ (LiTFSI), tetraethylene glycol dimethyl ether of $>99.00 \%$ purity (TEGDME), N-Methyl pyrrolidine of $>97 \%$ purity, and multi-walled carbon nanotubes (MWCNTs) with a diameter of 5-20 nm, length of $5 \mu \mathrm{m}$, and purity $>96 \%$ of carbon basis were purchased from Sigma Aldrich. Palladium (II) chloride was purchased from ACROS organics. PVDF (Polyvinylidene fluoride) was procured from Alfa Aesar. Fuel Cell Earth supplied the carbon cloth gas diffusion layer (CCGDL) with a thickness of $\sim 300 \mu \mathrm{m}$. Lithium chips with a purity $>99.90 \%$ and a Celgard polypropylene separator with a thickness of $\sim 25 \mu \mathrm{m}$ were bought from MTI Corp. Scheme 1 depicts the assembly of the batteries. 


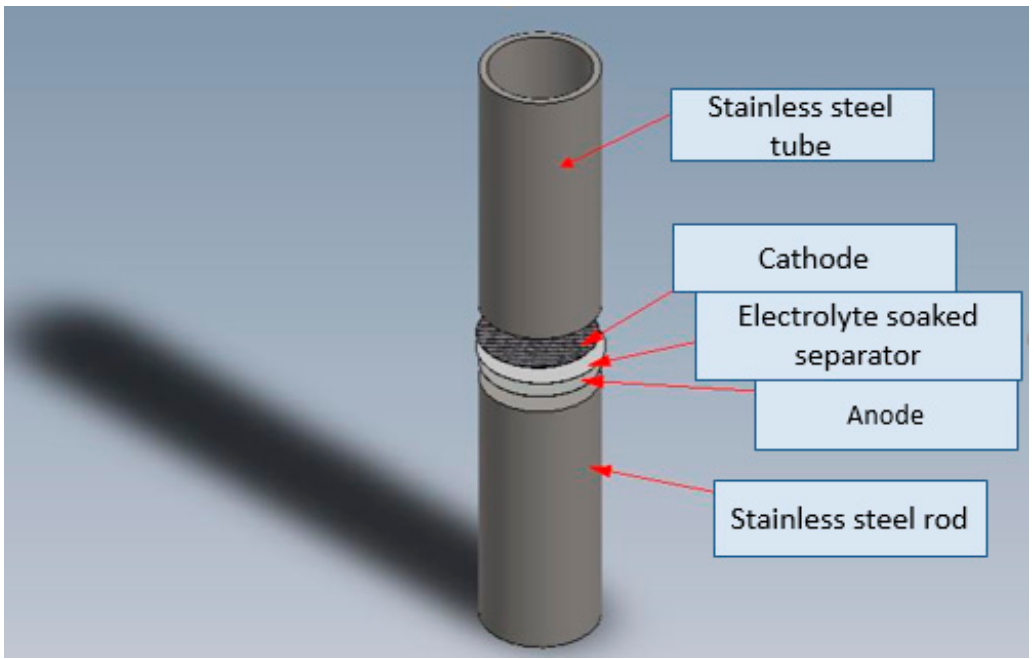

Scheme 1. Schematic depiction of the assembled $\mathrm{Li}^{-} \mathrm{O}_{2}$ batteries.

Preparation of the Electrode: We have followed the procedure for PF-CNTs preparation as described in our previous paper $[10,49]$. Briefly, nitric acid treatment was performed on the MWCNTs to decap the ends. $100 \mathrm{mg}$ of decapped multi-walled carbon nanotubes (MWCNTs) was blended with $1 \mathrm{mM}$ aqueous solution of $\mathrm{PdCl}_{2}$ until a slurry was formed. A similar procedure was followed on the untreated capped MWCNTs to obtain PC-CNTs. Both slurries were preserved at $25{ }^{\circ} \mathrm{C}$ for $10 \mathrm{~h}$ and then calcinated in air at $350{ }^{\circ} \mathrm{C}$ for $\sim 2 \mathrm{~h}$. Calcination was followed by hydrogenation that resulted in a yield of $\sim 5 \mathrm{wt}$.\% palladium nanoparticles. Preparation of cathode was as mentioned in the preceding paper [10]. Slurry of PVDF/PF and PC-CNT (10/90 wt.\% in N-Methyl-2-pyrrolidone or NMP) was used to coat the cathodes on carbon cloth with a $0.5^{\prime \prime}$ diameter. The cathodes were dried for 12 hours at $120^{\circ} \mathrm{C}$ and then stocked in an argon-filled glovebox. The loading of MWCNT was $0.39 \pm 0.01 \mathrm{mg} . \mathrm{cm}^{-2}$. All the capacities reported in this manuscript are per total mass of active cathode including the catalyst and CNTs.

Electrolyte Preparation and Battery Test Assembly: 1 M LiTFSI in TEGDME solution was used to prepare the electrolyte. Modified Swagelok-type cells were used for our battery assemblies. It consisted of a stainless-steel tube on the cathode side and a stainless-steel rod on the anode side. Celgard 2400 separator which was soaked with the electrolyte was arranged on the lithium metal disc anode. Then, the MWCNT-CCGDL was placed on it, followed by a stainless-steel mesh current collector. The batteries were then placed inside an Ar-filled glove box $\left(<1 \mathrm{ppm}_{2}\right.$ and $\left.<0.1 \mathrm{ppm} \mathrm{H}_{2} \mathrm{O}\right)$ for resting overnight before the electrochemical tests.

Electrochemical Characterizations: Before testing the batteries, they were rested under oxygen for $5 \mathrm{~h}$. Galvanostatic discharge/charge tests were performed on the Gamry $600^{\mathrm{TM}}$ Reference electrochemical workstation. Charge/discharge tests were performed within 2.0-4.5 V voltage range at a $250 \mathrm{~mA} \cdot \mathrm{g}^{-1}$ current density. The electrochemical characteristics of the cell were investigated by Electrochemical Impedance Spectroscopy (EIS) performed using a Gamry $600^{\mathrm{TM}}$ electrochemical workstation. Impedance data was collected in the frequency range of $10^{6}-0.01 \mathrm{~Hz}$. The environment was temperature-controlled at $25^{\circ} \mathrm{C}$ for all charge/discharge and electrochemical tests. After cycling, the oxygen cathodes were recovered, rinsed with dimethyl carbonate (DMC), and dried under vacuum inside the Ar-filled glove box.

Infrared Characterizations: The cathodes were investigated by FTIR (Fourier transform infrared) spectroscopy using JASCO FT-IR 4100 (company, city, country) for product characterization in the $500-4000 \mathrm{~cm}^{-1}$, mid-IR frequency region. A resolution of $4 \mathrm{~cm}^{-1}$ was used for each spectrum. For pretreatment for FTIR, the samples were rinsed three times with DMC (dimethyl carbonate) to remove the electrolyte salt from the cathode surface, and dried in vacuum to volatize the DMC. 


\section{Results and Discussion}

$\mathrm{Li}-\mathrm{O}_{2}$ batteries with cathodes comprising PC and PF-CNTs showed full discharge capacities of $\sim 8200 \mathrm{mAh} . \mathrm{g}^{-1}$ and $\sim 11,200 \mathrm{mAh} . \mathrm{g}^{-1}$, respectively [10]. The batteries were discharged to $2 \mathrm{~V}$ under oxygen. Galvanostatic cycling was employed to characterize the electrochemical properties on the cathodes during the OER and ORR processes. Cycle performance of the $\mathrm{Li}-\mathrm{O}_{2}$ batteries with PC-and PF-CNTs as cathodes were investigated at fixed capacities of $250 \mathrm{mAh} . \mathrm{g}^{-1}, 500 \mathrm{mAh} . \mathrm{g}^{-1}$, and $1000 \mathrm{mAh} . \mathrm{g}^{-1}$ at a $250 \mathrm{~mA} . \mathrm{g}^{-1}$ current density between 2.0-4.5 V (Figure 1). At $250 \mathrm{mAh} . \mathrm{g}^{-1}, 41$ and 81 cycles were obtained using PC-and PF-CNTs, respectively. At $500 \mathrm{mAh} . \mathrm{g}^{-1}, 44$ and 58 cycles were obtained using PC-and PF-CNTs, respectively. 16 and 25 cycles were obtained at $1000 \mathrm{mAh} . \mathrm{g}^{-1}$. Figure 2 shows the terminal discharge voltages of the batteries.
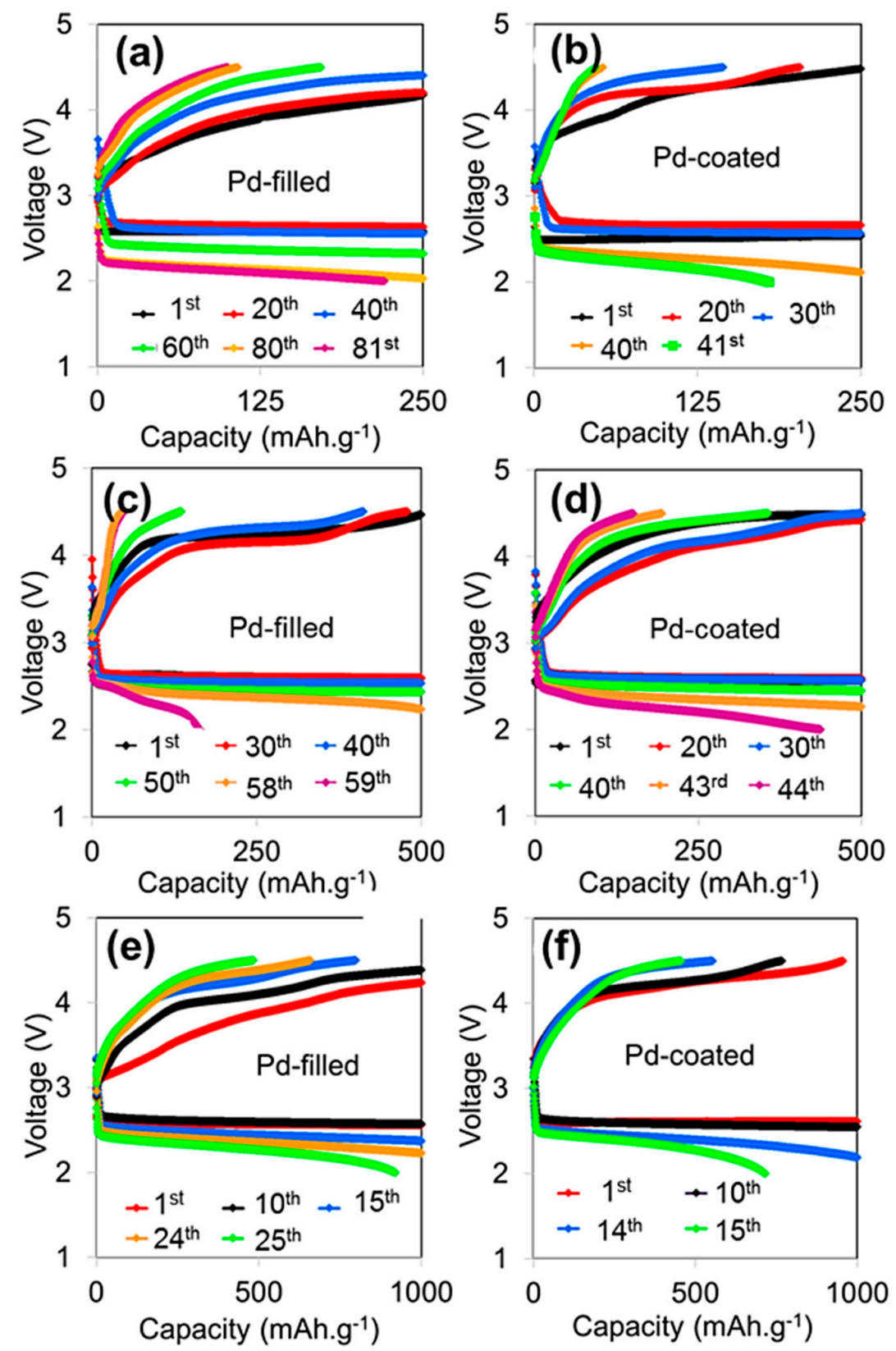

Figure 1. Voltage profile of lithium-oxygen $\left(\mathrm{Li}-\mathrm{O}_{2}\right)$ batteries with $(\mathbf{a}, \mathbf{c}, \mathbf{e})$ palladium-filled and $(\mathbf{b}, \mathbf{d}, \mathbf{f})$ palladium-coated carbon nanotubes (CNTs) at fixed capacities of $250 \mathrm{mAh} \cdot \mathrm{g}^{-1}, 500 \mathrm{mAh} \cdot \mathrm{g}^{-1}$, and $1000 \mathrm{mAh} . \mathrm{g}^{-1}$, respectively, at a $250 \mathrm{~mA} . \mathrm{g}^{-1}$ current density between 2.0 to $4.5 \mathrm{~V}$. 

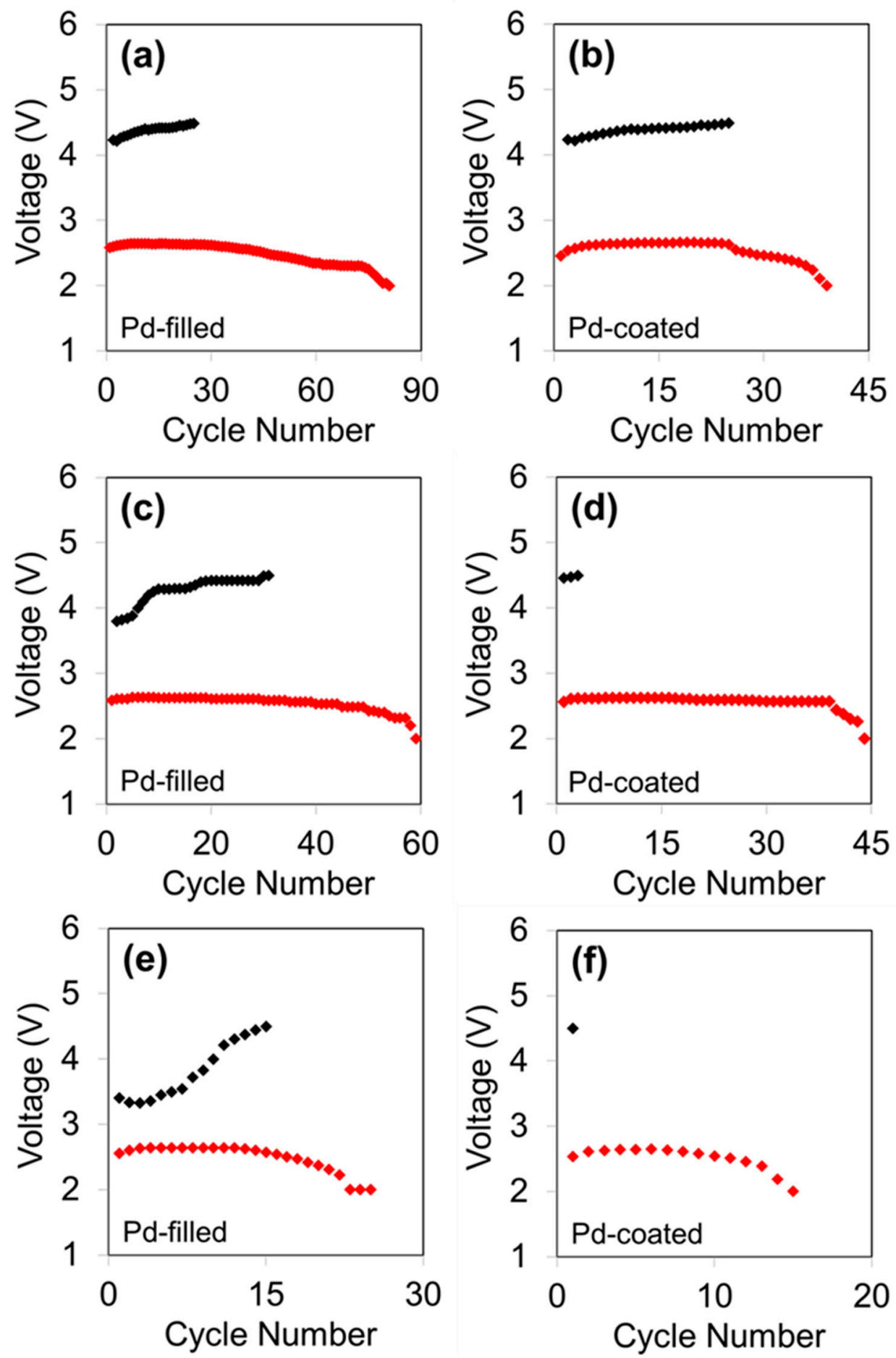

Figure 2. End charge/discharge voltages of $(\mathbf{a}, \mathbf{c}, \mathbf{e})$ palladium-filled and $(\mathbf{b}, \mathbf{d}, \mathbf{f})$ palladium-coated CNTs after full cycles to $250 \mathrm{mAh} . \mathrm{g}^{-1}, 500 \mathrm{mAh} . \mathrm{g}^{-1}$, and $1000 \mathrm{mAh} . \mathrm{g}^{-1}$, respectively.

EIS measurements were performed after discharge/charge cycles to investigate the cathode/electrolyte behavior during discharging and charging processes. The Nyquist plot after discharge shows a high-frequency intercept, $R_{b}$, which correlates to the resistance of cell, including contributions from the electrolyte, electrodes, and contact resistances [16,50-56], as shown in Figure $3 \mathrm{~g} . \mathrm{R}_{\mathrm{b}}$ is the high-frequency intercept and is obtained from the real EIS spectra. The EIS spectrum is followed by the semicircle that is associated with charge-transfer resistance at the 
cathode $/ \mathrm{O}_{2}$ /electrolyte interface [50-52], represented by $\mathrm{R}_{\text {int }}$ (interfacial resistance). $\mathrm{R}_{\text {int }}$ is obtained from the diameter of the semicircle of EIS. This is generally attributed to the $\mathrm{Li}_{2} \mathrm{O}_{2}$ which forms on the surface of the cathode after discharge, which hinders charge transfer and $\mathrm{O}_{2}$ diffusion through the pores of the cathode [51]. Following $\mathrm{R}_{\text {int }}$ there is a linear rise which is known as the Warburg-like linear region, which has also been reported in other metal- $\mathrm{O}_{2}$ battery EIS spectra at non-Faradaic conditions. In order to determine the impedance behavior of the porous electrodes in lithium-ion and metal- $\mathrm{O}_{2}$ batteries, the TLM or transmission line model was used. It is assumed that the Warburg-like linear region corresponds to the resistance of lithium-ion migration at the cathode, and is represented as $R_{\text {ion. }}$. We used a TLM model and estimated the $R_{\text {ion }}$ by the projection of the Warburg-like line on the impedance abscissa $\left(R_{\text {ion }} / 3\right)$, as shown in Figure $3 b[16,54]$.

In Figure 3, the Nyquist plot exhibits a semicircle with a smaller diameter for PF-CNT, and a semicircle with a bigger diameter for the PC-CNTs after the first discharge to $250 \mathrm{mAh} . \mathrm{g}^{-1}$. The semicircle diameter corresponds to the charge-transfer resistance [51]. Higher charge-transfer resistance leads to slower charge-transfer kinetics [51]. From Figure 4, it is evident that the PC-cathode has slower charge-transfer kinetics as compared to PF-CNTs, due to higher resistance. As the number of cycles increase, we can see a shift of the high-frequency intercept, $R_{b}$, toward the right. From Figure $3 a, b$ and Figure $4 a, b$, the shift is clearly visible for both cathodes. Figure 4 shows the change in the resistances after discharging the batteries to $250 \mathrm{mAh} \cdot \mathrm{g}^{-1}(\mathrm{a}, \mathrm{b}), 500 \mathrm{mAh} \cdot \mathrm{g}^{-1}(\mathrm{c}, \mathrm{d})$, and $1000 \mathrm{mAh} \cdot \mathrm{g}^{-1}$ $(\mathrm{e}, \mathrm{f})$. After the last discharging cycle up to $250 \mathrm{mAh} \cdot \mathrm{g}^{-1}$, which is 41 cycles for PC-CNT and 81 cycles of PF-CNT, respectively, Rb has shifted from $80 \Omega$ to $2910 \Omega$ for PC-CNT, whereas the shift of $R_{b}$ for PF-CNT is from $80 \Omega$ to $300 \Omega$ (Figure $4 a, b$ ). This shift in $R_{b}$ is attributed to electrolyte decomposition and formation of lithium carbonates over time. In Figure 4c, for PF-CNT discharged up to $500 \mathrm{mAh} . \mathrm{g}^{-1}$, the $R_{b}$ increases from $70 \Omega$ for the first cycle, to $300 \Omega$ for the last cycle. For PC-CNT (Figure $4 \mathrm{~d}$ ), the $R_{b}$ increases from $90 \Omega$ to $1700 \Omega$. In Figure 4e, for PF-CNT discharged up to 1000 mAh.g ${ }^{-1}$, the $R_{b}$ increases from $70 \Omega$ for the first cycle to $250 \Omega$ for the 25th cycle. However, in the case of PC-CNT (Figure $4 \mathrm{f}$ ), the $\mathrm{R}_{\mathrm{b}}$ increases from $80 \Omega$ to $1200 \Omega$. The gradual increase in the value of $\mathrm{R}_{\mathrm{b}}$ is credited to the slow accumulation of the reaction products, $\mathrm{Li}_{2} \mathrm{O}_{2}$ and $\mathrm{Li}_{2} \mathrm{O}$, within the pores of the carbon electrode, whereas the steep increase is an indication of a complete blockage of the carbon electrode that prevents further reduction of $\mathrm{O}_{2}$ [56]. This shift in $\mathrm{R}_{\mathrm{b}}$ is attributed to electrolyte decomposition and formation of lithium carbonate $\left(\mathrm{Li}_{2} \mathrm{CO}_{3}\right)$ over time [51]. As seen in Figure 4, $R_{\text {int }}$ decreases minimally for the first 30 cycles of PF-CNTs and then increases. For PC-CNTs, $R_{\text {int }}$ decreases for the first 10 cycles after the first discharge and then keeps increasing. $R_{\text {ion }}$ was the major resistance in both cathodes, and it keeps increasing with the number of cycles, as seen in the figure. Anode/electrolyte interface initially governs the interfacial resistance of $\mathrm{Li}_{-} \mathrm{O}_{2}$ batteries $[24,57]$. The initial decrease in the value of $R_{\text {int }}$ is mainly attributed to the dissolution of the passivation film on the anode/electrolyte film's interface [16]. Accumulation of irreversible discharge/charge by-products on the anode/electrolyte [16] and cathode/electrolyte interfaces [16,57] results in an increased $R_{\text {int }}$ value during later cycles. Yi et al. [58,59] showed that an increased interfacial resistance on the cathode/electrolyte interface in $\mathrm{Li}_{-} \mathrm{O}_{2}$ batteries could be the result of lithium carbonate by-product formation during cycling. According to Shui et al. [60], deactivation of the cathode leads to $\mathrm{Li}_{-} \mathrm{O}_{2}$ battery death. Increase in $\mathrm{R}_{\mathrm{ion}}$ during cycling is an indication that the cathode pores have been clogged, meaning that $\mathrm{Li}^{+}$ion transport is hindered [16]. 

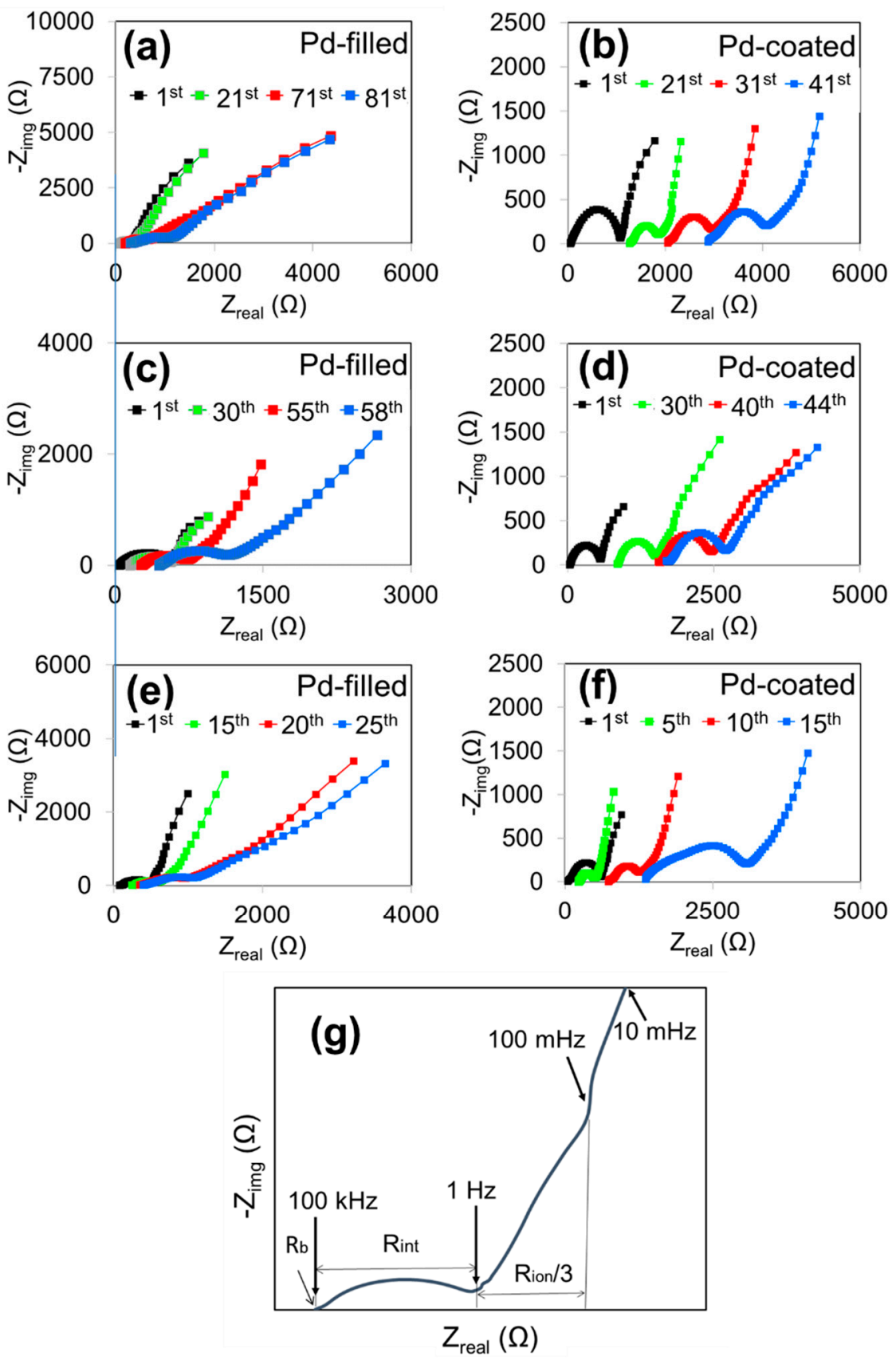

Figure 3. Nyquist plots of (a) PF- and (b) PC-CNTs after different discharging cycles of $250 \mathrm{mAh}^{-1}$ capacity; Nyquist plots of (c) PF- and (d) PC-CNTs after different discharging cycles of $500 \mathrm{mAh} . \mathrm{g}^{-1}$ capacity; and Nyquist plots of (e) PF- and (f) PC-CNTs after different discharging cycles of 1000 mAh.g ${ }^{-1}$ capacity. (g) Typical Nyquist plot. The batteries were cycled at $250 \mathrm{~mA} \cdot \mathrm{g}^{-1}$ with a current density between 2 to $4.5 \mathrm{~V}$. 

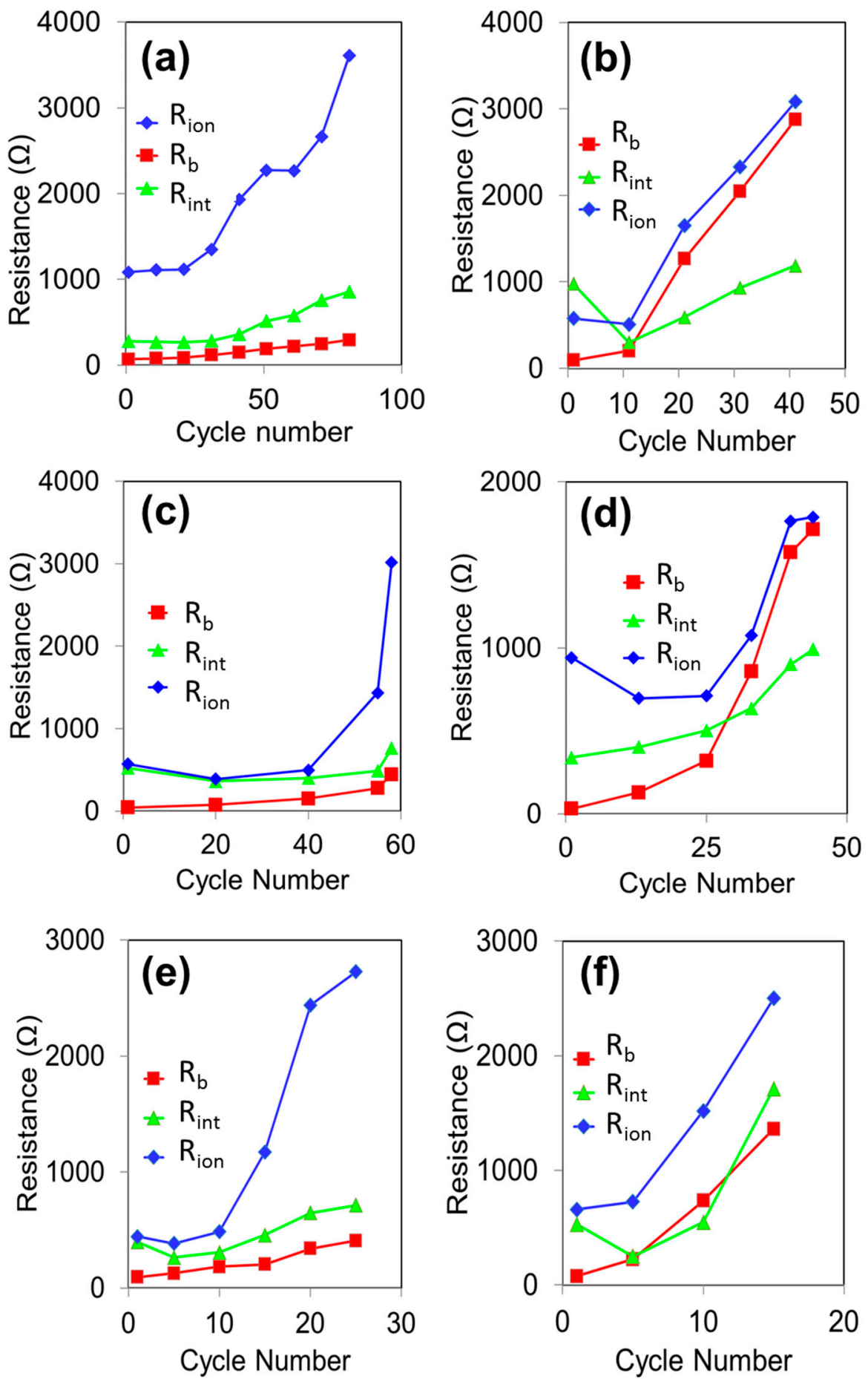

Figure 4. Change of resistances after the discharging $(\mathbf{a}, \mathbf{c}, \mathbf{e})$ Palladium-filled CNT, and $(\mathbf{b}, \mathbf{d}, \mathbf{f})$ palladium-coated CNT cycles of $250 \mathrm{mAh} \cdot \mathrm{g}^{-1}, 500 \mathrm{mAh} \cdot \mathrm{g}^{-1}$, and $1000 \mathrm{mAh} \cdot \mathrm{g}^{-1}$ capacities, respectively.

For the cycles of $1000 \mathrm{mAh} . \mathrm{g}^{-1}$ as the fixed capacity, similar Nyquist plots were observed (Figure 4c,d). In this case too, the PF-CNT was cycled for 25 cycles, as compared to 16 cycles with PC-CNTs. After the last discharging cycle of up to $1000 \mathrm{mAh} . \mathrm{g}^{-1}, \mathrm{R}_{\mathrm{b}}$ shifted from 80 to 1350 for PC-CNT, whereas the shift for PF-CNT was from 80 to 400. This indicates more electrolyte decomposition in the case of PC-CNTs. $R_{\text {ion }}$ had the highest resistance for both cases. Hence, in this case too, the battery failure was primarily due to pore-clogging. 
As shown by the EIS, the formation of $\mathrm{Li}_{2} \mathrm{O}_{2}$ hinders the charge transfer between the interfaces and the decomposition of electrolyte [16]. Both reasons lead to the failure of $\mathrm{Li}^{-} \mathrm{O}_{2}$ batteries. To investigate the composition of the deposits that clog the pores of the cathodes, we performed FTIR on PC and PF-CNT cathodes after cycling for 15 and 45 cycles at fixed capacities of $1000 \mathrm{mAh} . \mathrm{g}^{-1}$ and $250 \mathrm{mAh} \cdot \mathrm{g}^{-1}$. The peak at around $590 \mathrm{~cm}^{-1}$ is attributed to $\mathrm{Li}_{2} \mathrm{O}_{2}$, and $\mathrm{Li}_{2} \mathrm{CO}_{3}$ produces a peak at $862 \mathrm{~cm}^{-1}$ [61]. From Figure 5, it can be observed that the peaks of $\mathrm{Li}_{2} \mathrm{CO}_{3}$ are higher in the case of PC, rather than PF-CNTs. Better cycling was observed in PF-CNTs due to less undesirable products. The improvement in the cycling stability of PF-CNTs over the PC-CNTs was a result of the decrease in undesirable charge/discharge product formation, e.g., $\mathrm{Li}_{2} \mathrm{CO}_{3}$, caused by the encapsulation approach [10].

Figure 6 shows a comparison between PC-and PF-CNTs at capacities of 500, 1000, 1500, 5000, and $8000 \mathrm{mAh} . \mathrm{g}^{-1}$. As observed from the figure, at $500 \mathrm{mAh} \cdot \mathrm{g}^{-1}$, a Li $\mathrm{O}_{2}$ peak is present in both cathodes. A distinct $\mathrm{Li}_{2} \mathrm{CO}_{3}$ peak is observed for PC-CNT but is negligible in the case of PF-CNT. At all the capacities, $\mathrm{Li}_{2} \mathrm{O}_{2}$ peaks are present for both PC-and PF-CNT cathodes. However, the $\mathrm{Li}_{2} \mathrm{CO}_{3}$ peak for PF-CNT cathodes gradually increases as the capacity increases. Low $\mathrm{Li}_{2} \mathrm{CO}_{3}$ formation in the PF-CNT, as compared to PC-CNT results in increased battery performance [61].

SEM proved the formation of $\mathrm{Li}_{2} \mathrm{CO}_{3}$ dendrites on the cathode surface after cycling, as shown in Figure 7. When the batteries were cycled between 2.0 and $4.0 \mathrm{~V}$, there is a constant accumulation of lithium carbonate $\left(\mathrm{Li}_{2} \mathrm{CO}_{3}\right)$ arising from the reactions involving the electrode and electrolyte [62], which results in electrode passivation and capacity fading in cells with carbon electrodes. Lithium carbonates are also produced as a result of the side-reaction of lithium peroxide with moisture and carbon dioxide from the atmosphere. It is difficult to be decomposed, and considerably deteriorated the cycling life $[20,63]$. The large over-charge potential can induce the side-reaction of oxidation decomposition of the electrode and electrolyte during $\mathrm{Li}_{2} \mathrm{O}_{2}$ oxidation, which results in the formation of $\mathrm{Li}_{2} \mathrm{CO}_{3}$ [62]. The accumulation of $\mathrm{Li}_{2} \mathrm{CO}_{3}$ in the electrode led to electrode passivation and capacity-fading on cycling. The PC-CNT cathode shown in Figure $7 \mathrm{~b}$ presents platelet-shaped lithium peroxide $\left(\mathrm{Li}_{2} \mathrm{O}_{2}\right)$ covered by a thick conformal layer of lithium carbonates $\left(\mathrm{Li}_{2} \mathrm{CO}_{3}\right)$, as shown in the FTIR measurements whereas the PF-CNTs showed nano-thin platelets of $\mathrm{Li}_{2} \mathrm{O}_{2}$ canvasing the cathode (Figure 7a). Since the $\mathrm{Li}_{2} \mathrm{O}_{2}$ platelets yield high surface porosity, they do not block access to the CNTs which in turn enhances battery performance [10].
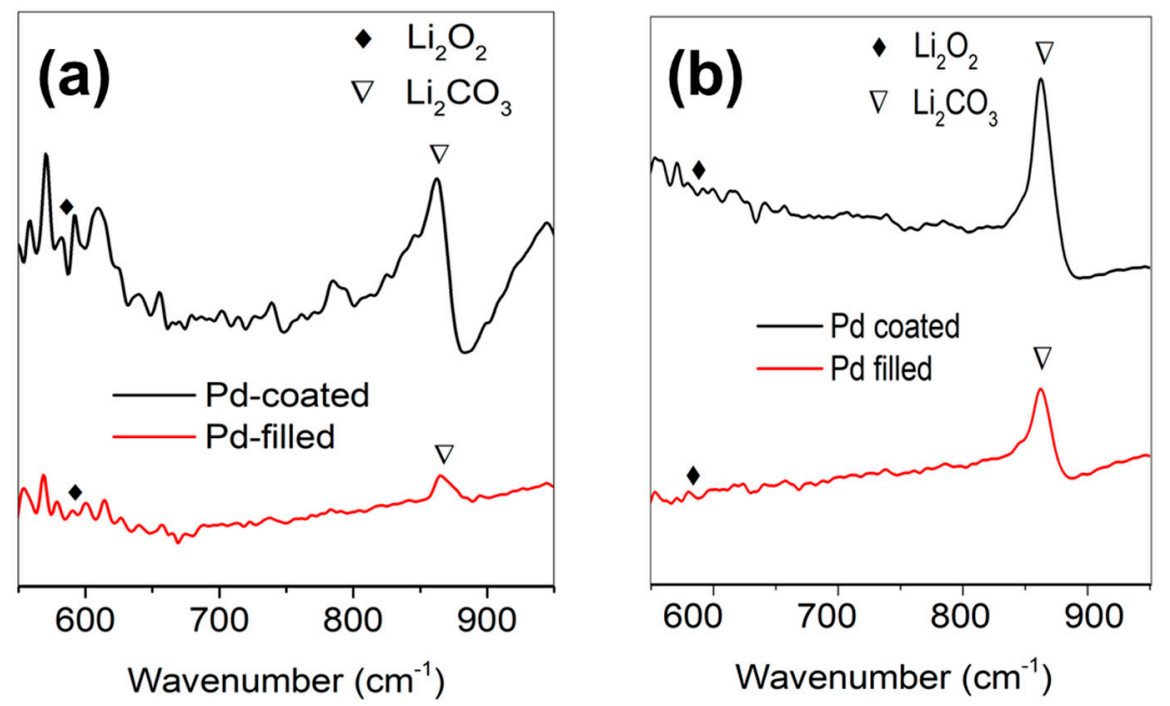

Figure 5. Fourier transform infrared (FTIR) spectra of PF- and PC-CNTs after cycling for (a) 45 cycles to $250 \mathrm{mAh} \cdot \mathrm{g}^{-1}$ and (b) 15 cycles to $1000 \mathrm{mAh} \cdot \mathrm{g}^{-1}$. 

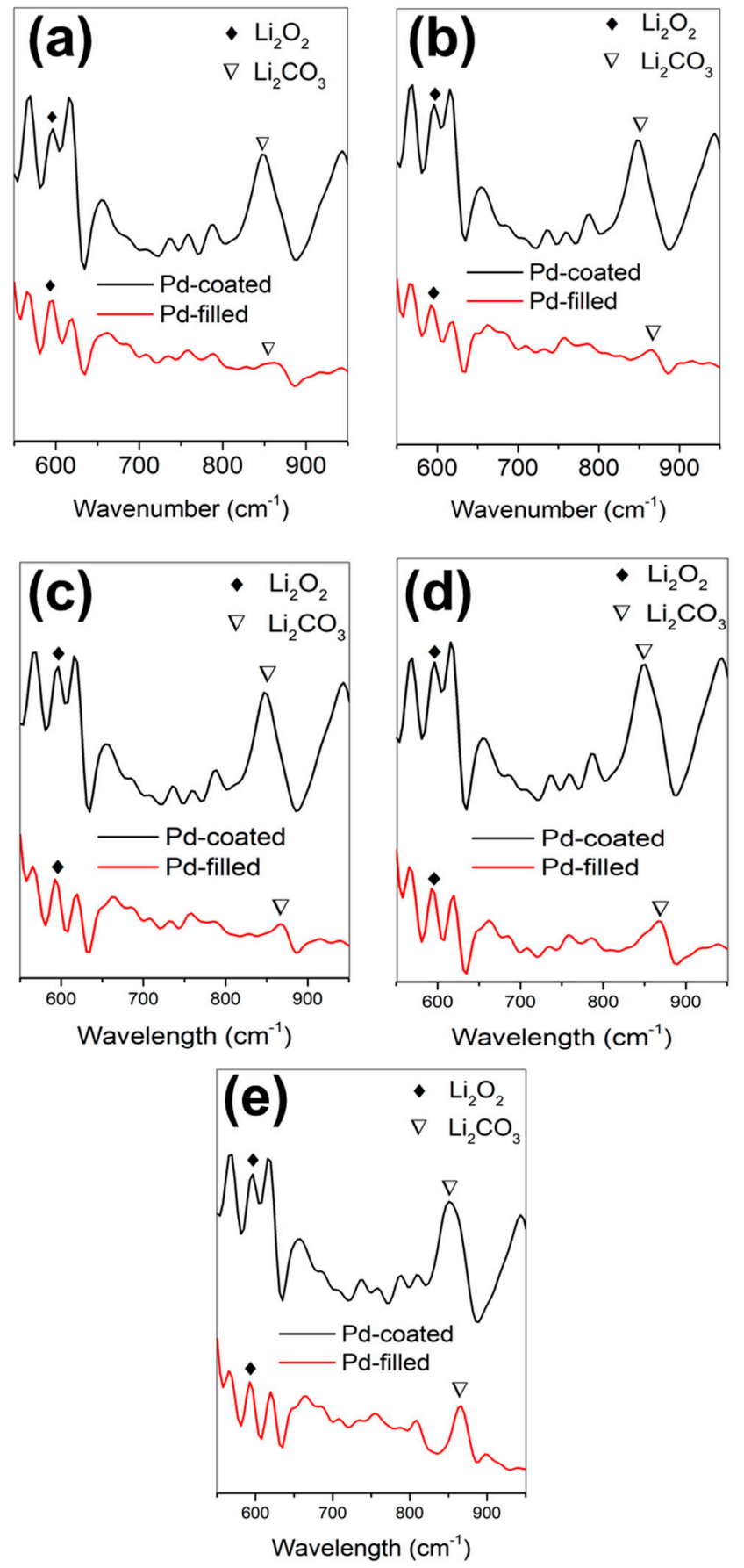

Figure 6. FTIR spectra after discharging to (a) $500 \mathrm{mAh} \cdot \mathrm{g}^{-1}$, (b) $1000 \mathrm{mAh} . \mathrm{g}^{-1}$, (c) $1500 \mathrm{mAh} . \mathrm{g}^{-1}$, (d) $5000 \mathrm{mAh} . \mathrm{g}^{-1}$, and (e) $8000 \mathrm{mAh} . \mathrm{g}^{-1}$. All batteries were discharged at $250 \mathrm{~mA} . \mathrm{g}^{-1}$ between 2 to $4.5 \mathrm{~V}$. 

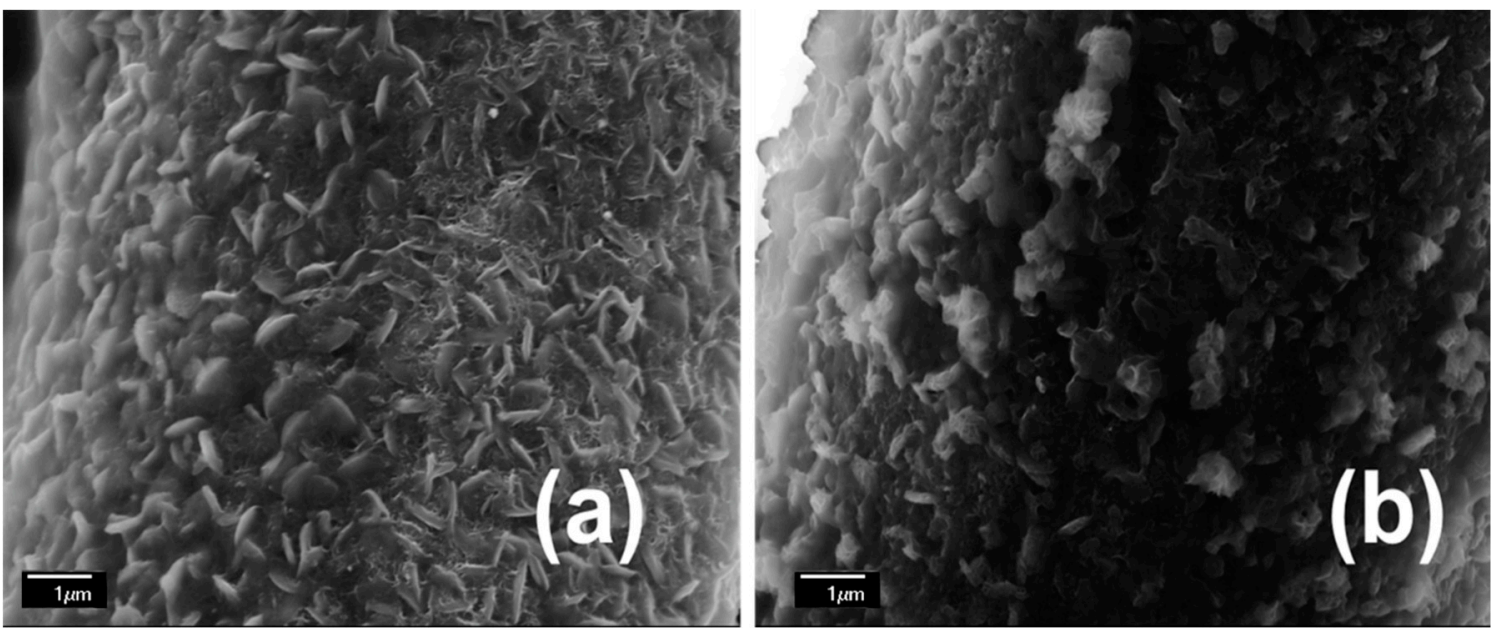

Figure 7. SEM images after cycling of (a) PF- and (b) PC-CNT cathodes.

As we demonstrated in our previous paper [10], the improvement in cycling stability of PF- CNTs over the PC-CNTs was a result of the decrease in undesirable charge/discharge product formation, e.g., $\mathrm{Li}_{2} \mathrm{CO}_{3}$, afforded by the encapsulation approach.

\section{Conclusions}

An EIS study was conducted in this paper on a $\mathrm{Li}^{-\mathrm{O}_{2}}$ battery utilizing PC-and PF- CNTs, and we provided insight into kinetics operating the battery operation. From EIS results, it was shown that $R_{\text {ion }}$ had the highest resistance, which indicates the failure of the batteries due to pore-clogging of the cathodes. Increasing $R_{b}$ resistamce indicates more electrolyte decomposition in the case of PC, rather than PF-, CNT cathodes. FTIR and SEM further confirm that PF-CNTs have better capacity-retention due to less $\mathrm{Li}_{2} \mathrm{CO}_{3}$ formation on the surface of the cathode, as compared to PC-CNTs.

Author Contributions: Investigation, N.C., A.C., M.S. and M.H.; Supervision, B.E.-Z.

Funding: This research received no external funding.

Acknowledgments: The authors acknowledge Peggy Wang's group for FTIR instrument use. N.C. and M.S. acknowledge Florida International University Dissertation Year Fellowship for the financial support. M.H. acknowledges the financial support of the McKnight Doctoral Fellowship.

Conflicts of Interest: The authors declare no conflict of interest.

\section{References}

1. Feng, N.; He, P.; Zhou, H. Critical Challenges in Rechargeable Aprotic Li- $\mathrm{O}_{2}$ Batteries. Adv. Energy Mater. 2016, 6, 1-24. [CrossRef]

2. Panchal, S.; Mathewson, S.; Fraser, R.; Culham, R.; Fowler, M. Thermal Management of Lithium-Ion Pouch Cell with Indirect Liquid Cooling using Dual Cold Plates Approach. SAE Int. J. Altern. Powertrains 2015, 4, 293-307. [CrossRef]

3. Safa, M.; Chamaani, A.; Chawla, N.; El-Zahab, B. Polymeric Ionic Liquid Gel Electrolyte for Room Temperature Lithium Battery Applications. Electrochim. Acta 2016, 213, 587-593. [CrossRef]

4. Panchal, S.; Mathewson, S.; Fraser, R. Experimental Measurements of Thermal Characteristics of LiFePO4 Battery; SAE Tech. Paper; SAE: Warrendale, PA, USA, 2015.

5. Geng, D.; Ding, N.; Hor, T.S.A.; Chien, S.W.; Liu, Z.; Wuu, D.; Sun, X.; Zong, Y. From Lithium-Oxygen to Lithium-air Batteries: Challenges and Opportunities. Adv. Energy Mater. 2016, 1-14. [CrossRef]

6. Landa-Medrano, I.; Li, C.; Ortiz-Vitoriano, N.; de Larramendi, I.R.; Carrasco, J.; Rojo, T. Sodium-Oxygen Battery: Steps Toward Reality. J. Phys. Chem. Lett. 2016, 7, 1161-1166. [CrossRef] [PubMed] 
7. Safa, M.; Hao, Y.; Chamaani, A.; Adelowo, E.; Chawla, N.; Wang, C.; El-Zahab, B. Capacity Fading Mechanism in Lithium-Sulfur Battery using Poly(ionic liquid) Gel Electrolyte. Electrochim. Acta 2017, 258, 1284-1292. [CrossRef]

8. Girishkumar, G.; McCloskey, B.; Luntz, A.C.; Swanson, S.; Wilcke, W. Lithium-air battery: Promise and challenges. J. Phys. Chem. Lett. 2010, 1, 2193-2203. [CrossRef]

9. Abraham, K.M.; Jiang, Z. A Polymer Electrolyte-Based Rechargeable Lithium/Oxygen Battery technical papers electrochemical science and technology A Polymer Electrolyte-Based Rechargeable lithium/Oxygen Battery. J. Electrochem. Soc. 1996, 143, 1-5. [CrossRef]

10. Chawla, N.; Chamaani, A.; Safa, M.; El-Zahab, B. PF- Carbon Nanotubes Cathode for Improved Electrolyte Stability and Cyclability Performance of $\mathrm{Li}^{-} \mathrm{O}_{2}$ Batteries. J. Electrochem. Soc. 2017, 164, A6303-A6307. [CrossRef]

11. Zhang, Y.; Zhang, H.; Li, J.; Wang, M.; Nie, H.; Zhang, F. The use of mixed carbon materials with improved oxygen transport in a Lithium-air battery. J. Power Sources 2013, 240, 390-396. [CrossRef]

12. Fuentes, R.E.; Colón-Mercado, H.R.; Fox, E.B. Electrochemical evaluation of carbon nanotubes and carbon black for the cathode of Li-air batteries. J. Power Sources 2014, 255, 219-222. [CrossRef]

13. Zhang, G.Q.; Zheng, J.P.; Liang, R.; Zhang, C.; Wang, B.; Hendrickson, M.; Plichta, E.J. Lithium-Air Batteries Using SWNT/CNF Buckypapers as Air Electrodes. J. Electrochem. Soc. 2010, 157, A953. [CrossRef]

14. Mitchell, R.R.; Gallant, B.M.; Thompson, C.V.; Shao-Horn, Y. All-carbon-nanofiber electrodes for high-energy rechargeable $\mathrm{Li}_{-} \mathrm{O}_{2}$ batteries. Energy Environ. Sci. 2011, 4, 2952. [CrossRef]

15. Li, Y.; Wang, J.; Li, X.; Liu, J.; Geng, D.; Yang, J.; Li, R.; Sun, X. Nitrogen-doped carbon nanotubes as cathode for lithium-air batteries. Electrochem. Commun. 2011, 13, 668-672. [CrossRef]

16. Chamaani, A.; Safa, M.; Chawla, N.; El-Zahab, B. Composite Gel polymer electrolyte for improved cyclability in lithium-oxygen batteries. ACS Appl. Mater. Interfaces 2017, 9, 33819-33826. [CrossRef]

17. Chamaani, A.; Chawla, N.; Safa, M.; El-Zahab, B. One-Dimensional Glass Micro-Fillers in Gel Polymer Electrolytes for $\mathrm{Li}_{2} \mathrm{O}_{2}$ Battery Applications. Electrochim. Acta 2017, 235, 56-63. [CrossRef]

18. Li, Y.; Wang, J.; Li, X.; Geng, D.; Banis, M.N.; Li, R.; Sun, X. Nitrogen-doped graphene nanosheets as cathode materials with excellent electrocatalytic activity for high capacity lithium-oxygen batteries. Electrochem. Commun. 2012, 18, 12-15. [CrossRef]

19. Zu, C.; Li, L.; Qie, L.; Manthiram, A. Expandable-graphite-derived graphene for next-generation battery chemistries. J. Power Sources 2015, 284, 60-67. [CrossRef]

20. Zhang, T.; Zhou, H. A reversible long-life Lithium-air battery in ambient air. Nat. Commun. 2013, 4, 1817. [CrossRef]

21. Lu, J.; Lei, Y.; Lau, K.C.; Luo, X.; Du, P.; Wen, J.; Assary, R.S.; Das, U.; Miller, D.J.; Elam, J.W.; et al. A nanostructured cathode architecture for low charge overpotential in lithium-oxygen batteries. Nat. Commun. 2013, 4, 2383. [CrossRef]

22. Astinchap, B.; Moradian, R.; Ardu, A.; Cannas, C.; Varvaro, G.; Capobianchi, A. Bifunctional FePt @ MWCNTs/Ru Nanoarchitectures: Synthesis and Characterization. Chem. Mater. 2012, 24, 3393-3400. [CrossRef]

23. Itkis, D.M.; Semenenko, D.A.; Kataev, E.Y.; Belova, A.I.; Neudachina, V.S.; Sirotina, A.P.; Hävecker, M.; Teschner, D.; Knop-Gericke, A.; Dudin, P.; et al. Reactivity of carbon in lithium-oxygen battery positive electrodes. Nano Lett. 2013, 13, 4697-4701. [CrossRef] [PubMed]

24. Chamaani, A.; Safa, M.; Chawla, N.; Herndon, M.; El-zahab, B. Stabilizing e ff ect of ion complex formation in lithium-Oxygen battery electrolytes. J. Electroanal. Chem. 2018, 815, 143-150. [CrossRef]

25. Rahman, M.A.; Wang, X.; Wen, C. A review of high energy density lithium-air battery technology. J. Appl. Electrochem. 2013, 44, 5-22. [CrossRef]

26. Yilmaz, E.; Yogi, C.; Yamanaka, K.; Ohta, T.; Byon, H.R. Promoting Formation of Noncrystalline $\mathrm{Li}_{2} \mathrm{O}_{2}$ in the $\mathrm{Li}_{2} \mathrm{O}_{2}$ Battery with $\mathrm{RuO}_{2}$ Nanoparticles. Nano Lett. 2013, 13, 4679-4684. [CrossRef] [PubMed]

27. Sun, B.; Munroe, P.; Wang, G. Ruthenium nanocrystals as cathode catalysts for lithium-oxygen batteries with a superior performance. Sci. Rep. 2013, 3, 1-7. [CrossRef] [PubMed]

28. Débart, A.; Paterson, A.J.; Bao, J.; Bruce, P.G. $\alpha-\mathrm{MnO}_{2}$ Nanowires: A Catalyst for the $\mathrm{O}_{2}$ Electrode in Rechargeable Lithium Batteries. Angew. Chem. Int. Ed. 2008, 47, 4521-4524. [CrossRef]

29. Chawla, N. Nanocatalysts in lithium oxygen batteries. Nano Sci. Nano Technol. Indian J. 2018, 12, 128. 
30. Lu, Y.C.; Gasteiger, H.a.; Shao-Horn, Y. Catalytic activity trends of oxygen reduction reaction for nonaqueous Li-air batteries. J. Am. Chem. Soc. 2011, 133, 19048-19051. [CrossRef]

31. Xu, J.-J.; Wang, Z.-L.; Xu, D.; Zhang, L.-L.; Zhang, X.-B. Tailoring deposition and morphology of discharge products towards high-rate and long-life lithium-oxygen batteries. Nat. Commun. 2013, 4, 2438. [CrossRef]

32. Zhao, G.; Niu, Y.; Zhang, L.; Sun, K. Ruthenium oxide modified titanium dioxide nanotube arrays as carbon and binder free lithium-air battery cathode catalyst. J. Power Sources 2014, 270, 386-390. [CrossRef]

33. Wang, Y.; Rong, Z.; Wang, Y.; Qu, J. Ruthenium nanoparticles loaded on functionalized graphene for liquid-phase hydrogenation of fine chemicals: Comparison with carbon nanotube. J. Catal. 2016, 333, 8-16. [CrossRef]

34. Guo, Z.; Zhou, D.; Liu, H.; Dong, X.; Yuan, S.; Yu, A.; Wang, Y.; Xia, Y. Synthesis of ruthenium oxide coated ordered mesoporous carbon nanofiber arrays as a catalyst for lithium oxygen battery. J. Power Sources 2015, 276, 181-188. [CrossRef]

35. Guo, X.; Liu, P.; Han, J.; Ito, Y.; Hirata, A.; Fujita, T.; Chen, M. 3D Nanoporous Nitrogen-Doped Graphene with Encapsulated $\mathrm{RuO}_{2}$ Nanoparticles for Li-O⿰亻 2 Batteries. Adv. Mater. 2015, 27, 6137-6143. [CrossRef] [PubMed]

36. Su, D.; Dou, S.; Wang, G. Gold nanocrystals with variable index facets as highly effective cathode catalysts for lithium-oxygen batteries. NPG Asia Mater. 2015, 7, e155. [CrossRef]

37. Li, F.; Tang, D.M.; Tao, Z.; Liao, K.; He, P.; Golberg, D.; Yamada, A.; Zhou, H. Superior performance of a Li-O 2 battery with metallic $\mathrm{RuO}_{2}$ hollow spheres as the carbon-free cathode. Adv Energy Mater. 2015, 5. [CrossRef]

38. Jian, Z.; Liu, P.; Li, F.; He, P.; Guo, X.; Chen, M.; Zhou, H. Core-shell-structured CNT@RuO 2 composite as a high-performance cathode catalyst for rechargeable $\mathrm{Li}^{-} \mathrm{O}_{2}$ batteries. Angew. Chem. Int. Ed. Engl. 2014, 53, 442-446. [CrossRef] [PubMed]

39. Oh, S.H.; Nazar, L.F. Oxide catalysts for rechargeable high-capacity Li-O $\mathrm{O}_{2}$ batteries. Adv. Energy Mater. 2012, 2, 903-910. [CrossRef]

40. Li, F.; Wu, S.; Li, D.; Zhang, T.; He, P.; Yamada, A.; Zhou, H. The water catalysis at oxygen cathodes of lithium-oxygen cells. Nat. Commun. 2015, 6. [CrossRef]

41. Yao, K.P.C.; Risch, M.; Sayed, S.Y.; Lee, Y.-L.; Harding, J.R.; Grimaud, A.; Pour, N.; Xu, Z.; Zhou, J.; Mansour, A.; et al. Solid-state activation of $\mathrm{Li}_{2} \mathrm{O}_{2}$ oxidation kinetics and implications for $\mathrm{Li}^{-\mathrm{O}_{2}}$ batteries. Energy Environ. Sci. 2015, 8, 2417-2426. [CrossRef]

42. Yao, K.P.C.; Lu, Y.-C.; Amanchukwu, C.V.; Kwabi, D.G.; Risch, M.; Zhou, J.; Grimaud, A.; Hammond, P.T.; Bardé, F.; Shao-Horn, Y. The influence of transition metal oxides on the kinetics of $\mathrm{Li}_{2} \mathrm{O}_{2}$ oxidation in $\mathrm{Li}-\mathrm{O}_{2}$ batteries: High activity of chromium oxides. Phys. Chem. Chem. Phys. 2014, 16, 2297-2304. [CrossRef] [PubMed]

43. Gittleson, F.S.; Sekol, R.C.; Doubek, G.; Linardi, M.; Taylor, A.D. Catalyst and electrolyte synergy in Li-O batteries. Phys. Chem. Chem. Phys. 2014, 16, 3230-3237. [CrossRef] [PubMed]

44. Gittleson, F.S.; Ryu, W.-H.; Schwab, M.; Tong, X.; Taylor, A.D. Pt and Pd catalyzed oxidation of $\mathrm{Li}_{2} \mathrm{O}_{2}$ and DMSO during $\mathrm{Li}_{-} \mathrm{O}_{2}$ battery charging. Chem. Commun. 2016, 52, 6605-6608. [CrossRef] [PubMed]

45. Ryu, W.H.; Gittleson, F.S.; Schwab, M.; Goh, T.; Taylor, A.D. A mesoporous catalytic membrane architecture for lithium-oxygen battery systems. Nano Lett. 2015, 15, 434-441. [CrossRef] [PubMed]

46. Schroeder, M.A.; Pearse, A.J.; Kozen, A.C.; Chen, X.; Gregorczyk, K.; Han, X.; Cao, A.; Hu, L.; Lee, S.B.; Rubloff, G.W.; et al. Investigation of the Cathode-Catalyst-Electrolyte Interface in Aprotic $\mathrm{Li}_{-} \mathrm{O}_{2}$ Batteries. Chem. Mater. 2015, 27, 5305-5313. [CrossRef]

47. Huang, X.; Yu, H.; Tan, H.; Zhu, J.; Zhang, W.; Wang, C.; Zhang, J.; Wang, Y.; Lv, Y.; Zeng, Z.; et al. Carbon nanotube-encapsulated noble metal nanoparticle hybrid as a cathode material for Li-oxygen batteries. Adv. Funct. Mater. 2014, 24, 6516-6523. [CrossRef]

48. Huang, J.; Zhang, B.; Xie, Y.Y.; Lye, W.W.K.; Xu, Z.L.; Abouali, S.; Garakani, M.A.; Huang, J.Q.; Zhang, T.Y.; Huang, B.; et al. Electrospun graphitic carbon nanofibers with in-situ encapsulated Co-Ni nanoparticles as freestanding electrodes for $\mathrm{Li}_{2} \mathrm{O}_{2}$ batteries. Carbon N. Y. 2016, 100, 329-336. [CrossRef]

49. Hevia, S.; Homm, P.; Cortes, A.; Núñez, V.; Contreras, C.; Vera, J.; Segura, R. Selective growth of palladium and titanium dioxide nanostructures inside carbon nanotube membranes. Nanoscale Res. Lett. 2012, 7, 342. [CrossRef] [PubMed]

50. Zhang, D.; Li, R.; Huang, T.; Yu, A. Novel composite polymer electrolyte for lithium air batteries. J. Power Sources 2010, 195, 1202-1206. [CrossRef] 
51. Cecchetto, L.; Salomon, M.; Scrosati, B.; Croce, F. Study of a Li-air battery having an electrolyte solution formed by a mixture of an ether-based aprotic solvent and an ionic liquid. J. Power Sources 2012, 213, $233-238$. [CrossRef]

52. Laoire, C.O.; Mukerjee, S.; Plichta, E.J.; Hendrickson, M.a.; Abraham, K.M. Rechargeable Lithium/TEGDME-LiPF-6/O $/ \mathrm{O}_{2}$ Battery. J. Electrochem. Soc. 2011, 158, A302. [CrossRef]

53. Kichambare, P.; Kumar, J.; Rodrigues, S.; Kumar, B. Electrochemical performance of highly mesoporous nitrogen doped carbon cathode in lithium-oxygen batteries. J. Power Sources 2011, 196, 3310-3316. [CrossRef]

54. Knudsen, K.B.; Nichols, J.E.; Vegge, T.; Luntz, A.C.; McCloskey, B.D.; Hjelm, J. An Electrochemical Impedance

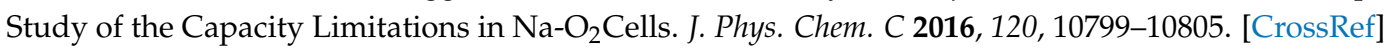

55. Højberg, J.; McCloskey, B.D.; Hjelm, J.; Vegge, T.; Johansen, K.; Norby, P.; Luntz, A.C. An electrochemical impedance spectroscopy investigation of the overpotentials in $\mathrm{Li}_{2} \mathrm{O}_{2}$ batteries. ACS Appl. Mater. Interfaces. 2015, 7, 4039-4047. [CrossRef] [PubMed]

56. Eswaran, M.; Munichandraiah, N.; Scanlon, L.G. High Capacity Li-O 2 Cell and Electrochemical Impedance. Electrochem. Solid-State Lett. 2010, 13, A121-A124. [CrossRef]

57. Bardenhagen, I.; Yezerska, O.; Augustin, M.; Fenske, D.; Wittstock, A.; Bäumer, M. In situ investigation of pore clogging during discharge of a $\mathrm{Li} / \mathrm{O}_{2}$ battery by electrochemical impedance spectroscopy. J. Power Sources 2015, 278, 255-264. [CrossRef]

58. Yi, J.; Wu, S.; Bai, S.; Liu, Y.; Li, N.; Zhou, H. Interfacial Construction of $\mathrm{Li}_{2} \mathrm{O}_{2}$ for a Performance-Improved Polymer Li- $\mathrm{O}_{2}$ Battery. J. Mater. Chem. A 2016, 4, 2403-2407. [CrossRef]

59. Yi, J.; Zhou, H. A Unique Hybrid Quasi-Solid-State Electrolyte for $\mathrm{Li}_{2} \mathrm{O}_{2}$ Batteries with Improved Cycle Life and Safety. ChemSusChem 2016, 9, 2391-2396. [CrossRef]

60. Shui, J.-L.; Okasinski, J.S.; Kenesei, P.; Dobbs, H.A.; Zhao, D.; Almer, J.D.; Liu, D.-J. Reversibility of anodic lithium in rechargeable lithium-oxygen batteries. Nat. Commun. 2013, 4, 1-7. [CrossRef]

61. Qiao, Y.; Ye, S. Spectroscopic Investigation for Oxygen Reduction and Evolution Reactions on Carbon Electrodes in $\mathrm{Li}_{-} \mathrm{O}_{2}$ Battery. J. Phys. Chem. C 2016, 120, 8033-8047. [CrossRef]

62. Thotiyl, M.M.O.; Freunberger, S.a.; Peng, Z.; Bruce, P.G. The carbon electrode in nonaqueous $\mathrm{Li}^{-\mathrm{O}_{2}}$ cells. J. Am. Chem. Soc. 2013, 135, 494-500. [CrossRef] [PubMed]

63. Luo, W.B.; Pham, T.V.; Guo, H.P.; Liu, H.K.; Dou, S.X. Three-Dimensional Array of TiN@Pt3Cu Nanowires as an Efficient Porous Electrode for the Lithium-Oxygen Battery. ACS Nano 2017, 11, 1747-1754. [CrossRef] [PubMed]

(C) 2019 by the authors. Licensee MDPI, Basel, Switzerland. This article is an open access article distributed under the terms and conditions of the Creative Commons Attribution (CC BY) license (http:/ / creativecommons.org/licenses/by/4.0/). 